\title{
An Examination on Customer Satisfaction Towards Air-Conditioner User in Chennai City
}

\author{
C.Kathiravan, V. Suresh, Padmaja Bhagavatham, V.Palanisamy
}

\begin{abstract}
The article tries to find out the customer satisfaction towards air-conditioner users in Chennai city. Two objective of this study is reached through proper methodology. Sample size was 200. Convenience sampling technique was used in this study. Reliability of this tool is 0.82 and 0.88 . Analysis was done through path analysis. It is found that there is influence of brand preference and factors determining purchase of air-conditioner on customer satisfaction towards air-conditioner. Research also identified that there is influence of customer satisfaction on brand loyalty towards air-conditioner. Hence, it is concluded that distributers and marketers require to framework best pricing strategies, star ratings, warranty and guarantee, product quality etc.
\end{abstract}

Keywords: Convenience Sampling Technique, Customer Satisfaction, Brand Preference, Brand Loyalty And Factors Determining Purchase of Air-Conditioner.

\section{INTRODUCTION}

Customer satisfaction is the one which is related to the individual consumer's perception over expected the performance of the air-conditioner with respect to consumer expectations (Schiffman \& Kanuk, 2010; Armstrong \& Kotler, 2010). Oliver (2010) opined that the satisfaction is the customer's fulfillment response. It is the personal judgment over an air-conditioner or service feature, which offers an agreeable level of consumption-related fulfillment. Zeithaml, et al. (2009) argued that breakdown to convene customer needs is unspecified to result in displeasure with the product of service. Hoyer and McInnis (2001) noticed and stated that satisfaction can be connected with approaches of excitement, acceptance, relief, happiness, and delight. Customer satisfaction has been attempted for a very long time to understand, to identify and to recognize in the field of marketing thoughts and practices. From the previous three decades or so customers' satisfaction was considered as a centralized idea as well as an essential goal to reach the target of sales in all business actions (Fornell, Anderson, and Lehmann 1994).

There are two different conceptualizations about customer satisfaction; one is transaction-specific satisfaction and the

Revised Manuscript Received on September 25, 2019

Dr.C.KATHIRAVAN , Associate Professor, Department of Business Administration, Annamalai University, India

V. SURESH, Doctoral Research Scholar, Dept. of Management Studies, Manonmanium Sundaranar University, Tirunelveli, Tamil Nadu, India

PADMAJA BHAGAVATHAM, Doctorial Research Scholar, Department of Business Administration, Annamalai University, India.

V.PALANISAMY, Doctorial Research Scholar, Department of Business Administration, Annamalai University \& Assistant Professor, St. Joseph University, Virgin Town, Ikishe Model Village, Dimapur, Nagaland, India.

additional is growing satisfaction. Transaction- specific satisfaction provided particular analytic information about a exacting product or service meet by the customer (Lam et al. 2004) Transaction- specific satisfaction increasing customer satisfaction is an overall assessment based on the total purchase and utilization experiences of the consumer with a product or service over a span of time (Anderson, et al. 1994); this type of satisfaction is more fundamental and useful than that of the business transaction - specific consumer satisfaction. Cumulative customer satisfaction is more comprehensive and efficient in predicting a consumers' subsequent behavior as well as a firm's past, present and future performances. It is the increasing customer satisfaction that encourages a firm to invest its time energy in understanding customer satisfaction (Wang, et al.2002).

\section{REVIEW OF LITERATURE}

Farbod Souri (2017) carries out a study to spot the connection between complete equity, complete loyalty and client satisfaction. To review analysis a sample of 384 customers was elite as a stepwise bunch. Information gathered by normal form with twenty three queries that its validity and dependability confirmed and was distributed among the applied math population. The study found that vital and positive relationship of brand name equity on client satisfaction and loyalty.

Gopi Krishnan (2017) studied the analysis of user's perception of client sturdy products: an empirical study with relevance province. A convenient sample of 902 shoppers United Nations agency owns white product white goods was chosen for the study. The study might modify to grasp the users' read and expectations supported the utility of refrigerators and conjointly the manufacturer can be ready to fulfill the necessity of the respondents in keeping with their preferences and perception.

Ritesh K. Patel (2013) conducted a study to spot the buyer preference towards purchase of electronic durable goods from retail malls. Descriptive analysis was undertaken. The scientist has used applied math techniques like Chi-square analysis and ANNOVA to succeed in at conclusion of this study. Study found that the factors like specific price profit, technological factors, promotional factors, social-culture, trust factors, satisfaction with retail mall square measure most significant factors that influence the buyer preference. Aslihan Nasir, et al. (2006) had analyzed the factors influencing consumer's laptop computer purchases. 327 samples were utilized in this study. Correlation analysis, ANOVA and frequency 
analysis were utilized in this study. The study showed that core technical options, post purchase services, worth and payment conditions, peripheral Specifications, physical look, price side options, and property and quality were the seven factors that were influencing consumers' laptop computer purchases. What is more, worth and payment conditions issue shows vital distinction among the buyer teams within the purchase of laptop computer.

He Xihao Stephen, et al. (2009) studied "Social influence on Consumers' buying Behaviour and connected promoting strategy. This comparative study was conducted between U.S. and China. Two hundred respondents were utilized in this study. 3 forms of reference cluster influence (informational influence, utilitarian influence, and value-expressive influence) were thought-about. The study indicated that there have been vital variations within the cellular phone client buying patterns. Conjointly 3 reference teams influenced each U.S. and China consumers' purchase behavior.

\section{RESEARCH METHODOLOGY}

\section{Research Design}

\section{Framework of the Study}

To find enhanced result to the research problem, an appropriate research plan is to be framed (Davis and Cosenza 1988; Cooper and Schindler 2001). Descriptive research design has been used for the current research. Descriptive study is a fact-finding examination with sufficient explanation.

\section{Research Gap}

Through the past literatures it was identified that some unrevealed truths are with the durable which include air conditioner. Some of the research gaps so far identified are related to (1) the dimensional structure of brand loyalty needs further investigation, (2) the relationships between brand loyalty and its factors have not been fully discovered, and (3) the effect of brand of origin, on brand loyalty and its factors has not been still fully determined. 4) There are several studies about the air-conditioner; but this study mainly identified the knowledge gap to be filled in relation to the 'air conditioner.

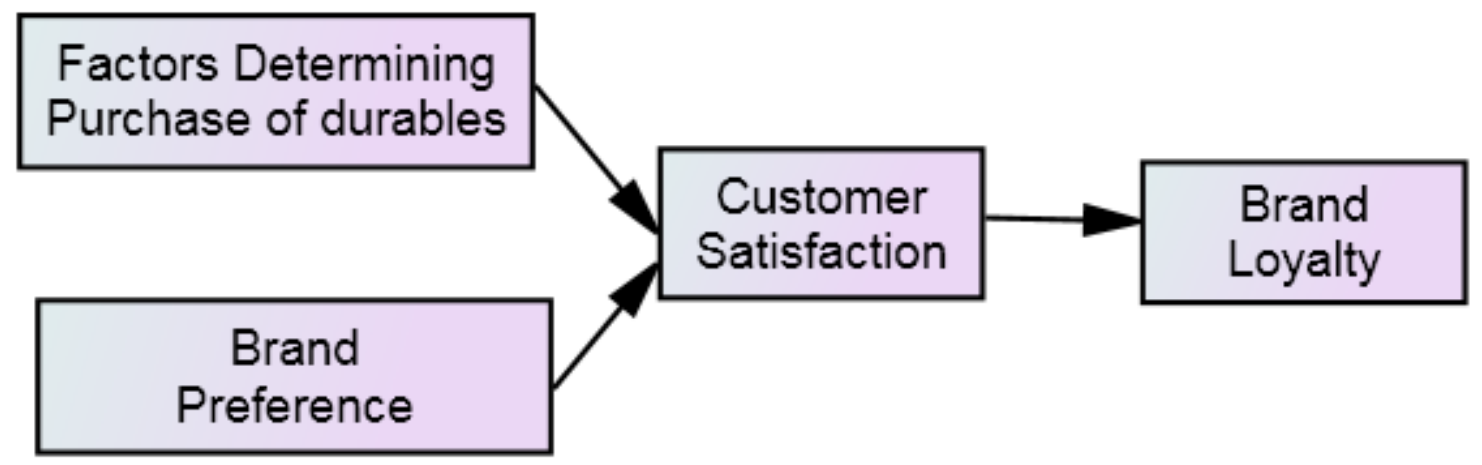

Figure 1: Conceptual Framework

This framework of the study is unique in introducing the outcome variable brand loyalty, mediator variable customer satisfaction and independent variables such as brand preference and factors determining purchase of air-conditioner.

\section{Questionnaire Construction}

\begin{tabular}{|c|l|c|c|}
\hline S.No. & \multicolumn{1}{|c|}{ Variable } & Item & Author \\
\hline $\mathbf{1}$ & Brand Preference & 15 & Prasanna (2012) \\
\hline $\mathbf{2}$ & $\begin{array}{l}\text { Factors Determining } \\
\text { Purchase of } \\
\text { Air-conditioner }\end{array}$ & 12 & Self Designed \\
\hline $\mathbf{3}$ & Customer Satisfaction & 21 & Nigel Douglas (2006) \\
\hline $\mathbf{4}$ & Brand Loyalty & 16 & \\
\hline
\end{tabular}

The brand preference scale was developed by Prasanna (2012). This variable includes 15 items; the statements are to lead to 5 point likert scale for the customers to respond. The factor determining purchase of air-conditioner scale was developed by Prasanna (2012).This variable includes 12 items; the statements are to lead to 5 point likert scale for the customers to respond. The customer satisfaction scale was developed by the researcher. Customer satisfaction includes 21 questions leading to 5 point likert scale for the customers to respond. The brand loyalty scale was developed by the Nigel Douglas (2006). It consists of 16 items for measuring three dimensions of customers towards brand loyalty in Chennai city. 
Table-II: Reliability Analysis

\begin{tabular}{|c|l|c|c|}
\hline S.No. & \multicolumn{1}{|c|}{ Variables } & item & Reliability \\
\hline $\mathbf{1}$ & Brand Preference & 15 & 0.88 \\
\hline $\mathbf{2}$ & Factors Determining Purchase of Air-conditioner & 12 & 0.82 \\
\hline $\mathbf{3}$ & Customer Satisfaction & 21 & 0.80 \\
\hline $\mathbf{4}$ & Brand Loyalty & 16 & 0.84 \\
\hline
\end{tabular}

Convenience sampling method is dictated only by the researcher's convenience and not to other considerations (Srivastava (2008). There is only a less effort needed to collect the data. Actually no pre plan of executing is there. Under this technique convenience sampling was opted. Sample size was 200. The standard deviation for this was 0.62. The sampling area was Chennai city. For all the items in the questionnaire construction, the reliability scores ranged from 0.78 to 0.88 . This shows high reliability of the statements in the questionnaires. With these results, fidelity, stability, and adoptability are established.

\section{Objective of the Study}

- To study the influence of brand preference and factors determining purchase of air-conditioner on customer satisfaction towards air-conditioner.

- To identify the influence of customer satisfaction on brand loyalty towards air-conditioner.

\section{Hypotheses of the Study}

- There is no influence of brand preference on customer satisfaction towards air-conditioner.

- There is no influence of factors determining purchase of air-conditioner on customer satisfaction towards air-conditioner.

- There is no influence of brand preference on brand loyalty towards air-conditioner.

- There is no influence of factors determining purchase of air-conditioner on brand loyalty towards air-conditioner.

- There is no influence of customer satisfaction on brand loyalty towards air-conditioner.

\section{Sampling Technique}

Convenience sampling technique was used for the study. Srivastava (2008) there is only a less effort need to collect the data. Actually no pre plan of executing is there.

\section{Data Collection}

The sample size of the study is 200 in all. The study was conducted in Chennai, Tamil Nadu. Questionnaire with 5 point scale is used.

\section{Statistical Tool Used}

Path analysis was adopted in this study. It is used to know the correlation and regression of independent variables with respect to customer satisfaction. Likewise the outcome variable brand loyalty, mediator variable customer satisfaction and independent variables such as brand preference and factors determining purchase of air-conditioner.

\section{ANALYSIS AND INTERPRETATION}

Table-III: Type of Air-conditioner

\begin{tabular}{|c|l|c|c|}
\hline Variable & Category & Frequency & Percentage \\
\hline \multirow{2}{*}{$\begin{array}{c}\text { Type of } \\
\text { Washing } \\
\text { Machine }\end{array}$} & Split AC & 140 & 70.00 \\
\cline { 2 - 4 } & Window AC & 48 & 24.00 \\
\cline { 2 - 4 } & Others & 12 & 6.00 \\
\cline { 2 - 4 } & Total & $\mathbf{2 0 0}$ & $\mathbf{1 0 0 . 0 0}$ \\
\hline
\end{tabular}

Source: primary data

Table III shows type of the air-conditioner. Out of the 200 customers 140 customers i.e. $70 \%$ of them are using split air-conditioner, whereas 48 customers i.e. $24 \%$ of them are using windows air-conditioner and 12 customers i.e. $6 \%$ of them are using other types of air-conditioner.

Table-IV: Brand of Air-conditioner

\begin{tabular}{|l|l|c|c|}
\hline Variable & Category & Frequency & Percentage \\
\hline \multirow{5}{*}{ Brand } & General & 44 & 22.00 \\
\cline { 2 - 4 } & Blue Star & 24 & 12.00 \\
\cline { 2 - 4 } & Voltas & 20 & 10.00 \\
\cline { 2 - 4 } & LG & 14 & 7.00 \\
\cline { 2 - 4 } & Others & 98 & 49.00 \\
\cline { 2 - 4 } & Total & $\mathbf{2 0 0}$ & $\mathbf{1 0 0 . 0 0}$ \\
\hline
\end{tabular}

Source: primary data

Table IV shows brand of the air-conditioner. Out of the 200 customers 44 customers i.e. $22 \%$ of them are using General air-conditioner, whereas 24 customers i.e. $12 \%$ of them are using Blue star air-conditioner, whereas 20 customers i.e. $10 \%$ of them are using Voltas air-conditioner, whereas 14 customers i.e. $7 \%$ of them are using LG air-conditioner and 98 customers i.e. $49 \%$ of them are using other brands of air-conditioner.

Table-V: Model Fit Indication

\begin{tabular}{|c|c|c|c|c|c|c|}
\hline $\begin{array}{c}\text { Chi- } \\
\text { Square }\end{array}$ & $\mathbf{p}$ & $\begin{array}{c}\text { RMSE } \\
\text { A }\end{array}$ & GFI & AFGI & CFI & NFI \\
\hline 2.042 & 0.132 & 0.027 & 0.996 & 0.942 & 0.999 & 0.995 \\
& & & & & & \\
\hline
\end{tabular}

From the above model fit indication table it is originate that the computed chi-square value was 2.042 and $\mathrm{p}$ value was 0.132 which was greater than 0.05 , which indicates that perfectly fit. Here GFI and AGFI values are greater than 0.90 which symbolize it is a good fit. The calculated CFI and NFI values are greater than 0.90 which means that it was an absolutely 
fit. It is found that RMSEA value is 0.027 , which was less than 0.08 , which shows that it is absolutely fit.

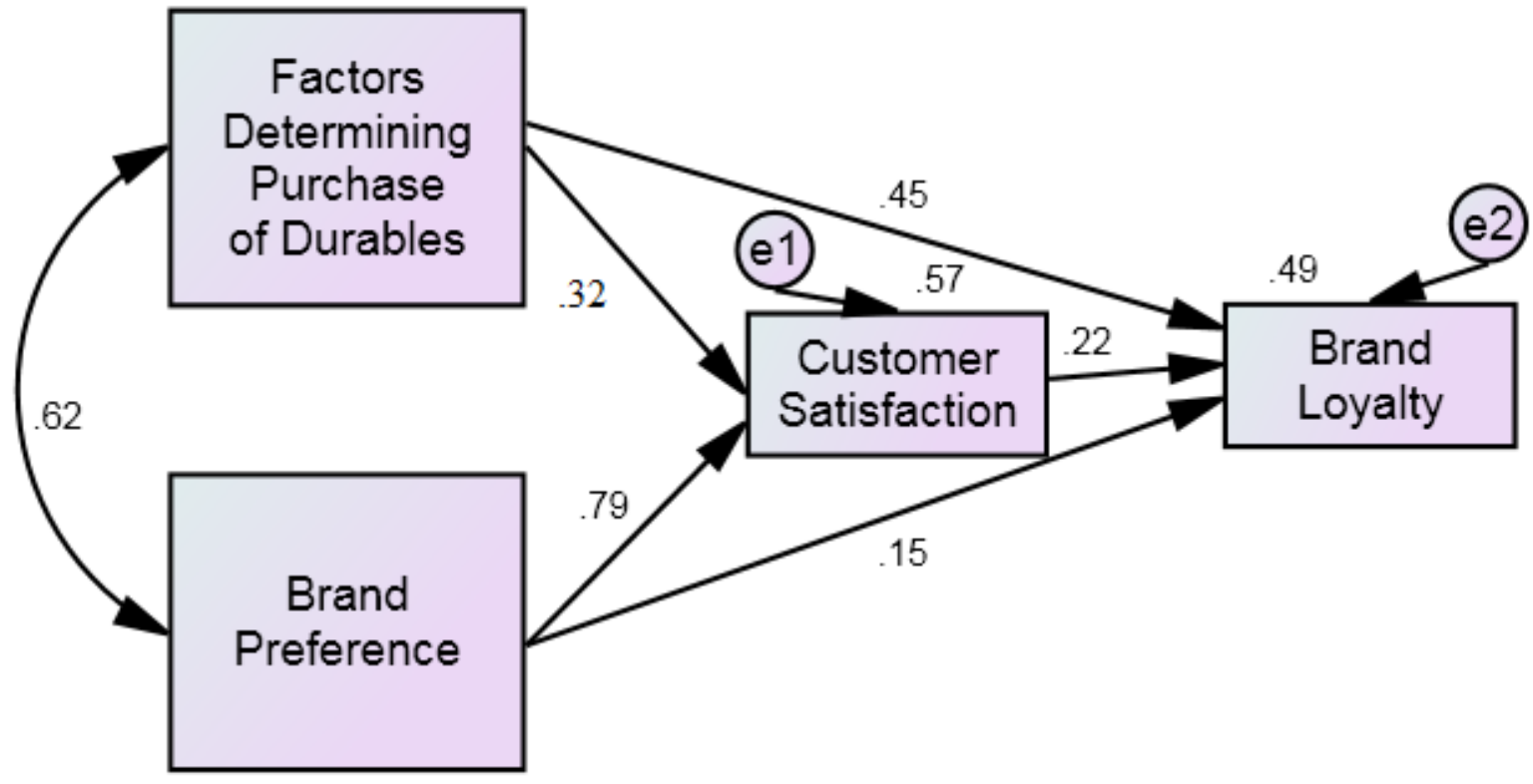

Table-VI: Regression Weights

\begin{tabular}{|l|l|l|l|l|l|l|c|}
\hline \multicolumn{1}{|c|}{ DV } & & \multicolumn{1}{|c|}{ IV } & Estimate & $\begin{array}{c}\text { S.E } \\
\text {. }\end{array}$ & $\begin{array}{c}\text { C.R } \\
.\end{array}$ & $\begin{array}{c}\text { Bet } \\
\mathbf{a}\end{array}$ & p \\
\hline $\begin{array}{l}\text { Customer } \\
\text { Satisfaction }\end{array}$ & $<---$ & $\begin{array}{l}\text { Factors Determining } \\
\text { Purchase Of Air-conditioner }\end{array}$ & 0.109 & 0.109 & 3.003 & 0.320 & $* * *$ \\
\hline $\begin{array}{l}\text { Customer } \\
\text { Satisfaction }\end{array}$ & $<---$ & Brand Preference & 1.184 & 0.089 & 13.312 & 0.788 & $* * *$ \\
\hline Brand Loyalty & $<---$ & Brand Preference & 0.117 & 0.041 & 2.839 & 0.219 & $\begin{array}{c}0.00 \\
5\end{array}$ \\
\hline Brand Loyalty & $<---$ & $\begin{array}{l}\text { Factors Determining } \\
\text { Purchase Of Air-conditioner }\end{array}$ & 0.121 & 0.071 & 2.710 & 0.152 & $\begin{array}{c}0.01 \\
7\end{array}$ \\
\hline Brand Loyalty & $<---$ & Customer Satisfaction & 0.435 & 0.063 & 6.882 & 0.445 & $* * *$ \\
\hline
\end{tabular}

Source: primary data

\section{Ho: There is no relationship between factors determining purchase of air-conditioner and brand preference.}

\section{HA: There is no relationship between factors determining purchase of air-conditioner and brand preference.}

Through the path analysis, covariance weight as the value of $\mathrm{CR}$ is 7.398 . The $\mathrm{r}$ value is 0.616 which indicates that $61.6 \%$ of relationship between factors determining purchase of air-conditioner and brand preference. The $p$ value is 0.001 ; here the $\mathrm{p}$ value is less than $5 \%$ and the hypothesis is rejected. Hence, it is concluded that there is no relationship between factors determining purchase of air-conditioner and brand preference.

\section{FINDINGS}

- There is an influence of brand preference on customer satisfaction towards air-conditioner.

- There is an influence of factors determining purchase of air-conditioner on customer satisfaction towards air-conditioner.
- There is an influence of brand preference on brand loyalty towards air-conditioner.

- There is an influence of factors determining purchase of air-conditioner on brand loyalty towards air-conditioner.

- There is an impact of customer satisfaction on brand loyalty towards air-conditioner.

\section{RECOMMENDATIONS}

- It is found that $70 \%$ of the customers own split air-conditioner, and there is a possibility for manufactures to change them to the newest trend other types of air-conditioner (Mobile air-conditioner and centralized air-conditioner).

- It is found that there is low influence of factors determining purchase of air-conditioner on customer satisfaction. Hence, it is recommended that distributers and marketers require to framework best 
pricing strategies, star ratings, warranty and guarantee, product quality etc.

- It is identified that a few brands like LG and Voltas though they are few in numbers among the customers. Hence, it is recommended that manufactures and marketers can rely on exclusive feature of their air-conditioner (color/star ratings/technology etc.) to be the chosen brand among consumers.

\section{CONCLUSION}

The path analysis found that there is influence of brand preference and factors determining purchase of air-conditioner on customer satisfaction towards air-conditioner. The study also found that there is influence of customer satisfaction on brand loyalty towards air-conditioner. Hence, it is concluded that distributers and marketers require to framework best pricing strategies, star ratings, warranty and guarantee, product quality etc.

\section{REFERENCES}

[1] Aslıhan Nasır, Sema Yoruker, Figen Güneș and Yeliz Ozdemir (2006) Factors Influencing Consumers Laptop Purchases, 6th Global conference \& Business \& Economics, 1-8.

[2] Cooper, D.R. \& Schindler, P.S. (2001), Business Research Methods, 7th edn., Irwin/ McGraw-Hill, Singapore.

[3] Davis, D. \& Cosenza, R.M. (1988), Business Research for Decision Making, 2nd edn., PWS-Kent, Boston.

[4] Farbod Souri (2017) Investigate The Relationship Between Brand Equity, Brand Loyalty And Customer Satisfaction. International Journal Of Scientific \& Technology Research, Volume 6, Issue 06, ISSN 2277-8616, pp-225-231.

[5] Gopi Krishnan (2017) analysis of user's perception of consumer durable products: an empirical study with reference to Tamil Nadu, department of management studies St. Peter's Institute of higher education and research, pp 1-182.

[6] He Xihao (Stephen) and Jiaqin Yang (2009) Social influence on Consumers' Purchasing Behaviour and related marketing strategy - a cross - nation comparative study.

[7] Ritesh K. Patel (2013) a study on consumer preference towards purchase of electronic consumer durables from retail malls, elk Asia pacific journal of marketing and retail management, ISSN 0976-7193 (Print) ISSN 2349-2317 (Online) Volume 4 Issue 3.

[8] Srivastava, \& T, N. (2008) Statistics for Management (1 st Edition Ed.), New Delhi: Tata McGraw Hills. 